\title{
Koszty jakości w strategii przedsiębiorstwa
}

\section{Przemysław Niewiadomski}

\author{
Uniwersytet Zielonogórski \\ E-mail: \\ p.niewiadomski@wez.uz.zgora.pl \\ ORCID: 0000-0002-2805-4671
}

\section{Bogdan Nogalski}

Wyższa Szkoła Bankowa w Gdańsku

E-mail:

bogdannogalski.bn@gmail.com ORCID: 0000-0003-0262-8355
Publikacja sfinansowana przez: Małopolska Wyższa Szkoła Ekonomiczna w Tarnowie

Korespondencja:

Przemysław Niewiadomski Uniwersytet Zielonogórski Instytut Nauk o Zarządzaniu i Jakości, ul. Podgórna 50 65-246 Zielona Góra Tel.: + 48692446716

\begin{abstract}
Abstrakt: Zasadniczym celem pracy jest zdefiniowanie kosztów jakości (rozpoznanie kierunku postrzegania), określenie ich miejsca i roli w strategii przedsiębiorstwa produkcyjnego. Badania odniesiono do producentów części i podzespołów maszyn rolniczych przeznaczonych na pierwszy montaż. Osiągnięcie celu głównego wymagało sformułowania i zrealizowania celów cząstkowych, do których autorzy zaliczają: (1) wyartykułowanie znaczenia kosztów jakości z perspektywy nauk o zarządzaniu i jakości (warstwa teoretyczna); (2) wytypowanie deskryptów odnoszących się istotnie do treści i zakresu prowadzonych badań; (3) skompilowanie modelu badawczego w postaci arkusza oceny będącego wypadkową eksploracji piśmiennictwa oraz badania zrealizowanego wśród celowo dobranych ekspertów (warstwa teoretyczno-projektowa). Skonkretyzowane eksplikacje stały się substratem definiującym właściwy kierunek fundamentalnych prac badawczych (weryfikacja modelu badawczego); konkretyzacja dezyderatów kosztów jakości wśród producentów sektora maszyn rolniczych (samoocena).
\end{abstract}

Słowa klucze: koszty jakości, strategia przedsiębiorstwa, produkcja na pierwszy montaż, sektor maszyn rolniczych

\section{Wprowadzenie}

Ciągłe i dynamiczne przeobrażenia (Petrus, 2019, s. 28-36), które dokonują się w otoczeniu zewnętrznym przedsiębiorstw, stawiają firmom coraz to wyższe wymagania i trudniejsze problemy do rozwiązania (Li, Liu, 2014, s. 2793-2799). Jednym z decydujących warunków osiągania sukcesu rynkowego staje się zatem projektowanie procesów dostosowanych do określonych potrzeb i możliwości (Agbejule, 2005, s. 295-305). Nie chodzi o to, by wdrażać produkty za wszelką cenę, nie zwracając uwagi na związane z daną implementacją koszty i wysokość ewentualnych zysków (Jespersen, Bysted, 2016; Abernethy, Lillis, 1995). Podejmując decyzje implementacyjne producent musi być pewny, że stopa zwrotu z wdrażanego produktu jest na tyle wysoka, iż poniesione 
koszty zostają zrównoważone ${ }^{1}$. Wobec tego przedsiębiorstwa zamierzając zwiększyć ekonomiczną efektywność posiadanych zasobów i realizowanych procesów (Gupta, Govindarajan, 1984, s. 25-41), powinny stosować nowoczesne metody i skuteczne sposoby zarządzania (Huefner, Largay, 2008, s. 245-255; Hoque, 2011, s. 266-277). Wymaga to z jednej strony ustalenia, czy dotychczasowa działalność przyniosła zamierzone efekty, z drugiej zaś, podejmowania działań nakierowanych na racjonalne wykorzystanie zasobów produkcyjnych, co wpływa również na skuteczność realizacji wykonywania przez organizację zadań (Bouwens, Abernethy, 2000, s. 221-241).

W warunkach nasilających się zmian należy poszukiwać narzędzi, które umożliwią przeprowadzanie nawet najbardziej skomplikowanych analiz (Strauß, Zecher, 2013; Teece, 2007; Burnes, 2000; Baldegger, 2012). Zwiększa się zatem rola jakości, która w działalności przedsiębiorstw zajmuje coraz bardziej znaczące miejsce. W systemie informacji ekonomicznej przedsiębiorstwa niezmiernie ważną rolę pełni zatem rachunkowość zarządcza (Hall [ed.], 2011; Mia, Chenhall, 1994; Mia, Patiar, 2001), która jest podstawowym źródłem informacji dotyczących kosztów (Abernethy, Guthrie, 1994, s. 49-66). Prawidłowo prowadzony rachunek kosztów służy ustalaniu efektów oraz umożliwia kontrolę gospodarności i stanowi bazę dla podejmowania trafnych decyzji ekonomicznych (Chenhall, 2003, s. 127-168).

Ewidencję, analizę i wykorzystanie rachunku kosztów jakości umożliwia dobrze zaprojektowany, wdrożony i stale doskonalony system zapewnienia jakości. Tymczasem kwerenda literatury wskazuje jednoznacznie, że koszty jakości - zarówno przez teoretyków, jak i praktyków zarządzania - nie zostały do tej pory precyzyjnie dookreślone. Różnice odnoszą się istotnie do treści i zakresu kosztów w strategii przedsiębiorstwa. W kontekście powyższego podjęto badania mające na celu precyzyjne zdefiniowanie kosztów jakości (rozpoznanie kierunku postrzegania), określenie ich miejsca i roli w strategii przedsiębiorstwa produkcyjnego. Badania odniesiono do producentów części i podzespołów maszyn rolniczych przeznaczonych na pierwszy montaż.

Osiągnięcie celu głównego wymagało sformułowania i zrealizowania celów cząstkowych, do których autorzy zaliczają: (1) wyartykułowanie znaczenia kosztów jakości z perspektywy nauk o zarządzaniu i jakości (warstwa teoretyczna); (2) wytypowanie deskryptów odnoszących się istotnie do treści i zakresu prowadzonych badań; (3) skompilowanie modelu badawczego w postaci arkusza oceny będącego wypadkową eksploracji piśmiennictwa oraz badania zrealizowanego wśród celowo dobranych ekspertów (warstwa teoretyczno-projektowa). Skonkretyzowane eksplikacje stały się substratem definiującym właściwy kierunek fundamentalnych prac badawczych (weryfikacja modelu badawczego); konkretyzacja dezyderatów kosztów jakości wśród producentów sektora maszyn rolniczych (samoocena).

\section{Koszty jakości - perspektywa nauk o zarządzaniu i jakości}

Jakkolwiek precyzyjne określenie kosztów jakości jest utrudnione z powodu występowania wielu obszarów, w których nakładają się na siebie działania związane z jakością i ściśle powiązane z procesem wytwarzania, to bez wątpienia są narzędziem umożliwiającym wska-

${ }^{1}$ Problematykę dotyczącą zarządzania kosztami w działalności przedsiębiorstw wyartykułowano m.in. w pracach: Nowak, 1994; Nowak, 2010; Nowak, 2015; Nowak, 2017; Nowak, Wierzbiński, 2010. 
zanie słabych punktów w procesach podstawowych i pomocniczych realizowanych w przedsiębiorstwie. Według E. Skrzypek (2003, s. 415-439) koszty jakości to miara efektywności działań związanych z funkcjonującym systemem zarządzania jakością. Koszty jakości powstające $\mathrm{w}$ przedsiębiorstwie stanowią pochodną całego systemu zarządzania i skuteczne narzędzie zmniejszania kosztów własnych przedsiębiorstwa. Poszukiwanie sposobów optymalizacji kosztów stanowi czynnik strategiczny przy wdrażaniu zasad kompleksowego zarządzania jakością w przedsiębiorstwie. Należy podkreślić, że wielkość i struktura kosztów winna być pomocna kierownictwu przedsiębiorstwa przy wyborze i realizacji długookresowych zamierzeń, np. przy wyznaczaniu celów i planów strategicznych oraz sterowaniu ich realizacją. Konieczna jest przy tym znajomość wielkości kosztów oraz zasadniczych relacji, jakie pomiędzy nimi zachodzą. Informacje kosztowe muszą być zatem dostępne, czytelne i wszechstronnie analizowane i wykorzystywane przy podejmowaniu decyzji.

Ze względu na wymogi wydawnicze co do objętości opracowania w niniejszym tekście nie zostały zaprezentowane szczegółowe rozważania nad istotą i pojęciem kosztów jakości². Stwierdzono, że można dokonać wyłącznie ich syntetycznego opisu w kontekście celu niniejszego opracowania, tym bardziej że istotne (szczegółowe) rozważania funkcjonują w literaturze naukowej z tego zakresu (Masser, 1957, s. 5-8; Harrington, 1987, s. 54; Lisiecka, 1999, s. 11; Zymonik, 2000, s. 76; Shah, Mandal, 1999, s. 1093-1106; Porter, Rayner, 1992, s. 69-71; Kister, 2005; Obied-Allah, 2016, s. 173-189).

E. Deming definiuje koszty jakości jako takie, które nie tworzą wartości dodanej. Wynikają one z „filozofii tolerowania błędów, pomyłek, opóźnień, przeoczeń”, stanowiących konsekwencję przypadkowych zdarzeń, które wymykają się spod kontroli, a ich źródłem jest system i jego otoczenie. Prezentowane podejście ujmuje jakość w terminach niezawodności, przewidywalności, pewności oraz zgodności z charakterystyką. W takim rozumieniu doskonalenie jakości jest tożsame z redukcją czynników zmiennych, prowadzącą do podniesienia wydajności i obniżenia kosztów (Skrzypek, 2000, s. 231-232).

Według P. Crosby’ego, koszty jakości obejmują zarówno koszty niezgodności, jak i zgodności. Przez pojęcie kosztu niezgodności, jego zdaniem, należy rozumieć wszelkie wydatki związane z niewłaściwym wykonaniem określonego zadania, natomiast koszty zgodności obejmują nakłady na zagwarantowanie prawidłowej realizacji wytycznych (Karaszewski, Skrzypczyńska, 2013, s. 51). Według J.M. Juran i F.M. Gryna (1974, s. 69) koszty jakości określają pewne wydatki związane z zapewnieniem produktom przydatności do użytku. Autorzy postulują, że redukcja kosztów jakości jest kluczowym determinantem obniżki kosztów własnych produkcji. Podkreśla się zatem, że celem każdej firmy powinna być minimalizacja kosztów związanych z niską jakością. Wskazuje to na konieczność dążenia do wykrywania źródeł błędów oraz ich eliminacji. Jakkolwiek początek prac nad redukcją kosztów jakości jest bardzo trudny, to z doświadczeń praktycznych wynika, że koszty te wykazują tendencję spadkową, jeśli podejmuje się prace zmierzające do ich ujawnienia ${ }^{3}$.

Według K. Lisieckiej (2000, s. 313) koszty jakości wyrażają skwantyfikowany cel zapewnienia jakości, który sprowadza się do doboru takiej struktury wydatków, przy której łączna suma strat i nakładów ponoszonych na działania zapewniające jakość będzie najmniejsza.

\footnotetext{
${ }^{2}$ Niemniej jednak dokonano prezentacji istotnych z perspektywy badań definicji.

${ }^{3}$ Zob.: (Skrzypek, 1999, s. 5-13).
} 
Koszty jakości definiuje się również jako koszty uzyskania pewności, że klient otrzymywać będzie tylko te produkty, które zostały wykonane zgodnie ze specyfikacją wymagań i wedle jego oczekiwań (Nixon, 1974, s. 38).

Jak podaje S. Zając (2014, s. 163-183) na koszty jakości składają się ponoszone nakłady lub utracone korzyści jako skutek niedoskonałości działania. Obejmują koszty niskiego poziomu jakości, koszty badania poziomu jakości i koszty przedsięwzięć zapobiegawczych. Według autora należy bardzo ostrożnie podchodzić do najczęściej spotykanego rozumienia kosztów jakości, jako kosztów tzw. złej jakości, rozpatrywanych w kategoriach strat spowodowanych błędami. Koszty jakości to nie tylko bowiem koszty błędów, ale również koszty działań, które mają zapobiegać powstawaniu tych błędów. Koszty jakości można rozszerzyć o zagadnienia ekologiczne. Z tej perspektywy A. Chodyński [2000] koszty jakości ekologicznej rozpatruje przez pryzmat sumy kosztów poniesionych dla zapewnienia określonego poziomu jakości wyrobów z uwzględnieniem ich cech ekologicznych, przy optymalizacji kosztów w działaniach systemowych w zakresie jakości oraz ochrony środowiska naturalnego, przy ustabilizowanym poziomie generacji wyrobów i procesów ich wytwarzania.

W opinii R. Karaszewskiego [2001] pojęcie kosztów jakości nie jest precyzyjnie definiowane zarówno przez praktyków, jak i teoretyków z dziedziny nauk o zarządzaniu i jakości. Różnice dotyczą treści, zakresu i obszarów powstawania kosztów jakości. Często są one niewłaściwie uznawane za koszy obsługi jakości, kontroli prawidłowości wykonania, czy też koszty funkcjonowania działu jakości.

W tej części opracowania wyartykułowano jak rozumieć koszty jakości, szczególnie w kontekście realizowanych badań. W związku z powyższym przedstawiono kilka kluczowych definicji dotyczących ich pojmowania.

$Z$ terminem koszty jakości wiąże się wiele niejasności. Termin ten jest pojęciem wielokontekstowym, co powoduje trudności w jego definiowaniu i klasyfikowaniu. Powstało zamieszanie metodologiczne, które nierzadko prowadzi do sprzecznych opinii, a nawet sporów, dotyczących tego, czym w istocie są koszty jakości, a co za tym idzie - jakimi metodami je badać, a następnie oceniać. Mimo wielu prób uzgodnienia stanowisk wśród badaczy brak jest jednoznacznej zgody w kwestii znaczenia wskazanego pojęcia. W szczególności swoiste zamieszanie jest spowodowane następującymi czynnikami: (1) istnieje wiele pomysłów, podejść oraz koncepcji dotyczących kosztów jakości; (2) opracowania na temat kosztów jakości koncentrują się głównie na ich charakterystyce, co w rezultacie wpływa na mnogość definicji i sposobów ich postrzegania; (3) koszty jakości mają charakter interdyscyplinarny, wpływają na nie różne nurty i podejścia badawcze; (4) obserwuje się przenoszenie osiągnięć naukowych z innych dyscyplin naukowych bez wyraźnego zaznaczenia pochodzenia i znaczenia omawianych pojęć.

W kontekście powyższego w niniejszej pracy podjęto próbę uporządkowania terminologicznego. Przedstawione celowo - wyartykułowane przez ekspertów - definicje, mają walor poznawczy, co w założeniu autorów ma umożliwić wychwycenie wspólnych obszarów, zależności i podejść badawczych. Zakłada się bowiem, że systematyzacja różnych ujęć tego samego problemu zwiększa szansę na kompleksową analizę, a także może stanowić inspirację do dalszych poszukiwań badawczych. 


\section{Materiał i metoda}

Sformułowane pytania badawcze oraz przekonanie o występowaniu gospodarczego zapotrzebowania na wyniki o charakterze aplikacyjnym, z jednej strony stanowiły główną inspirację do podjęcia badań, z drugiej zaś stały się punktem wyjścia do opracowania przedłożonej procedury badawczej. Schemat realizacji badań przedstawiono na rysunku 1.

Wykorzystując metodę rekonstrukcji i interpretacji literatury [B1] przedmiotu, bazując na doświadczeniu własnym badaczy (praktyka zawodowa, obserwacja uczestnicząca): (1) wytypowano katalog mikrofundamentów definiujących koszty jakości (rozpoznano kierunek postrzegania); (2) wyartykułowano ich miejsce i wskazano na rolę w strategii przedsiębiorstwa produkcyjnego.

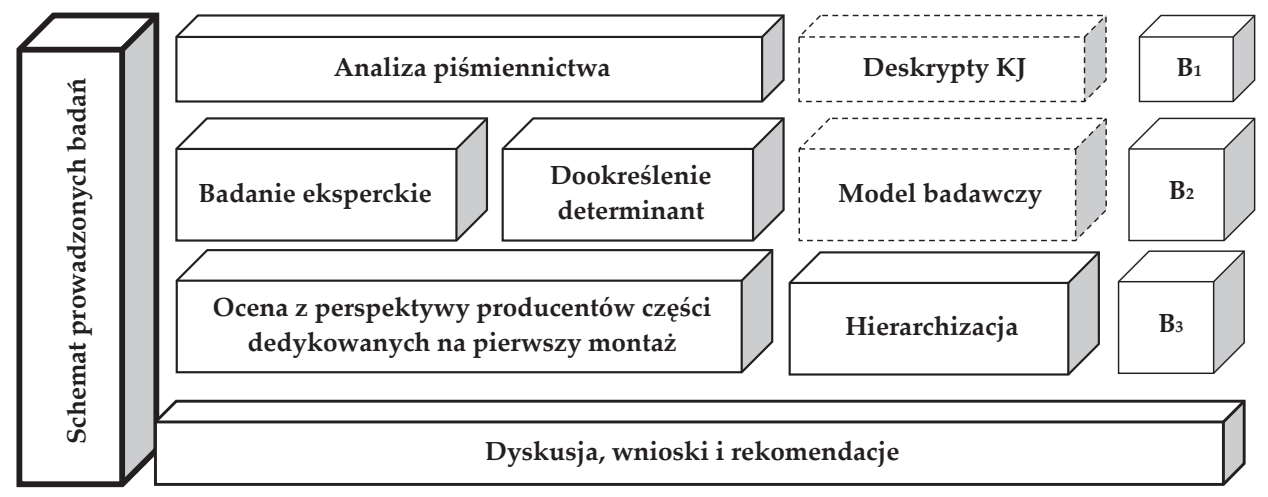

Rysunek. 1. Schemat realizacji badań

Źr ód ło: opracowanie własne.

Jako że wiele źródeł podaje, że techniki bazujące na grupach ludzi, mogą być bardziej skuteczne niż zbiór indywidualnych wysiłków (Paulus, Dzindolet, Poletes, Camacho, 1993, s. 78-89; Brown, Paulus, 2002, s. 208-212; Mumford, Gustafson, 1998, s. 27-43), w celu zweryfikowania trafności doboru poszczególnych determinant przeprowadzono kolejne badanie $\left[\mathrm{B}_{2}\right]$ przy wykorzystaniu wiedzy ekspertów dziedzinowych. Zidentyfikowane w badaniach literaturowo-projektowych determinanty poddano szczegółowej weryfikacji. Przyjęto bowiem, że aby możliwe było dyskutowanie o kluczowych parametrach identyfikujących koszty jakości niezbędne jest ich zredukowane metodą eksperckiego zorganizowania. W tym celu powołano zespół oceniający składający się z siedmiu celowo dobranych ekspertów dziedzinowych (tabela 1$)^{4}$.

${ }^{4} \mathrm{~W}$ skład zespołu oceniającego weszli wyłącznie specjaliści od rozwiązywanego problemu, co zweryfikowano na podstawie współczynnika kompetencyjności. Wyraża zależność współczynnika informatywności [Ki] (znajomości danego zagadnienia) i współczynnika argumentacji [Ka] (wyznaczono się na podstawie wywiadu $\mathrm{z}$ danym ekspertem). 
Tabela 1. Charakterystyka ekspertów zespołu oceniającego $\left[\mathrm{B}_{2}\right]$

\begin{tabular}{|c|c|c|c|}
\hline Instytucja / Stanowisko & Symbol & Specjalizacja & ${ }^{\mathrm{w}} \mathbf{K}$ \\
\hline $\begin{array}{l}\text { Przedsiębiorstwo produkcyjne sektora } \\
\text { maszyn rolniczych (Zarząd) }\end{array}$ & G.W. & $\begin{array}{l}\text { Zarządzanie strategiczne, nadzór } \\
\text { właścicielski, zarządzanie ciągłością } \\
\text { działania }\end{array}$ & 0,9 \\
\hline Dr hab. inż. (Politechnika Poznańska) & A.S. & $\begin{array}{l}\text { Dojrzałość, doskonałość, odporność } \\
\text { organizacji }\end{array}$ & 0,95 \\
\hline $\begin{array}{l}\text { Profesor uczelni (Uniwersytet } \\
\text { Zielonogórski) }\end{array}$ & D.S. & Zarządzane wartością & 0,95 \\
\hline $\begin{array}{l}\text { Przedsiębiorstwo handlowe sektora maszyn } \\
\text { rolniczych (Członek zarządu) }\end{array}$ & W.B. & $\begin{array}{l}\text { Rachunkowość menedżerska, } \\
\text { rachunek kosztów działań }\end{array}$ & 1,0 \\
\hline $\begin{array}{l}\text { Przedsiębiorstwo produkcyjne sektora } \\
\text { maszyn rolniczych (Menedżer Jakości) }\end{array}$ & B.P. & $\begin{array}{l}\text { Utrzymanie i rozwój zintegrowanego } \\
\text { systemu zarządzania (dostawy na } \\
\text { pierwszy montaż) }\end{array}$ & 0,9 \\
\hline $\begin{array}{l}\text { Sieć Badawcza Łukasiewicz - Przemysłowy } \\
\text { Instytut maszyn Rolniczych (Laboratorium } \\
\text { Badawcze Maszyn Rolniczych - kierownik) }\end{array}$ & K.B. & $\begin{array}{l}\text { System zarządzania, zgodny z normą } \\
\text { PN-EN ISO/IEC 17025:2018-02 }\end{array}$ & 0,85 \\
\hline $\begin{array}{l}\text { Pełnomocnik ds. Zintegrowanego Systemu } \\
\text { Zarządzania (ISO 9001, ISO 14001, ISO } \\
\text { 45001). }\end{array}$ & K.S. & $\begin{array}{l}\text { System zarządzania jakością; system } \\
\text { zarządzania środowiskowego; system } \\
\text { zarządzania bezpieczeństwem i higieną } \\
\text { pracy; audyt w zintegrowanym } \\
\text { systemie zarządzania }\end{array}$ & 1,0 \\
\hline
\end{tabular}

Źr ód ło: opracowanie własne.

W związku z niemożnością zorganizowana spotkania bezpośredniego, zastosowanie znalazła tzw. „wirtualna” burza mózgów. Wykorzystanie narzędzi informatycznych (ZOOM) pozwoliło wyeliminować trudności związane z organizacją i prowadzeniem sesji generowania pomysłów. Połączenie tradycyjnej metody pracy grupowej z systemem komputerowym stworzyło możliwość zorganizowania spotkania „w sieci” i wpłynęło na pozytywne efekty procesu weryfikacji pomysłów. Dzięki takiemu rozwiązaniu - celem wytypowania najistotniejszych parametrów - każdy zaproszony użytkownik mógł przedstawić swoje propozycje a pozostali członkowie „,wirtualnej” społeczności mogli nad nimi debatować (selekcja pomysłów).

Ogólna liczba ekspertów i skład grupy wiązały się z szerokością rozwiązywanego problemu i wiarygodnością ekspertyzy. Wielkość rozwiązywanego problemu określiła potrzebę włączenia do ekspertyzy specjalistów dziedzinowych. Liczbę ekspertów powiązano z obszarem różnorodnych aspektów, czynników, które należało uwzględnić przy rozwiązywaniu podjętego zagadnienia.

Mające charakter fenomenologiczny badania eksperckie umożliwiły rozpoznanie opinii, odczuć i skojarzeń, które wywołane były w analizowanym przypadku szeregiem czynników odnoszących się do problemu postrzegania kosztów jakości. Ponadto potwierdziły sens i celowość realizacji kolejnego etapu badania i dostarczyły interesujących informacji na temat języka, którym opisywane są przez branżowych ekspertów procesy będące przedmiotem definiowania; pozwoliło to uniknąć błędów na poziomie modelowania narzędzia badawczego implikującego realizację badania zasadniczego $\left[\mathrm{B}_{3}\right]$. 
Populację badanych podmiotów stanowiły 34 przedsiębiorstwa produkcyjne działające w sektorze maszyn rolniczych, które poza działalnością podstawową (produkcja części zamiennych, podzespołów i gotowych maszyn rolniczych) realizują także dostawy na pierwszy montaż. Biorąc pod uwagę rozkład ze względu na przeważający charakter produkcji były to przedsiębiorstwa deklarujące produkcję masową lub wielkoseryjną $(67,65 \%)$, produkcję krótkoseryjną (20,59\%), a także produkcję jednostkową (11,76\%). W przypadku 29,41\% (10) firm produkcja polega głównie na montowaniu komponentów nabywanych od zewnętrznych dostawców, natomiast 70,59\% (24) przedsiębiorstw deklarowało proces produkcyjny obejmujący przynajmniej kilka faz, w ramach których powstają wyroby gotowe, w tym przeznaczone na pierwszy montaż.

Biorąc pod uwagę wskazane ograniczenia (badania prowadzono w czasie pandemii wywołanej chorobą COVID-19) respondentami byli właściciele $(44,16 \%)$ i menedżerowie $(55,84 \%)$ reprezentujący: mikro -9 osób $(8,82 \%)$, małe -22 osoby $(14,71 \%)$, średnie 42 osoby $(64,71 \%)$ oraz duże - 4 osoby $(11,76 \%)$ przedsiębiorstwa, w tym $32,47 \%$ stanowili ankietowani w przedziale wiekowym do 40 lat, 35,06\% w przedziale wiekowym 41-50, $22,08 \%$ w przedziale 51-60 lat, natomiast 10,39\% badanych miało powyżej 60 lat.

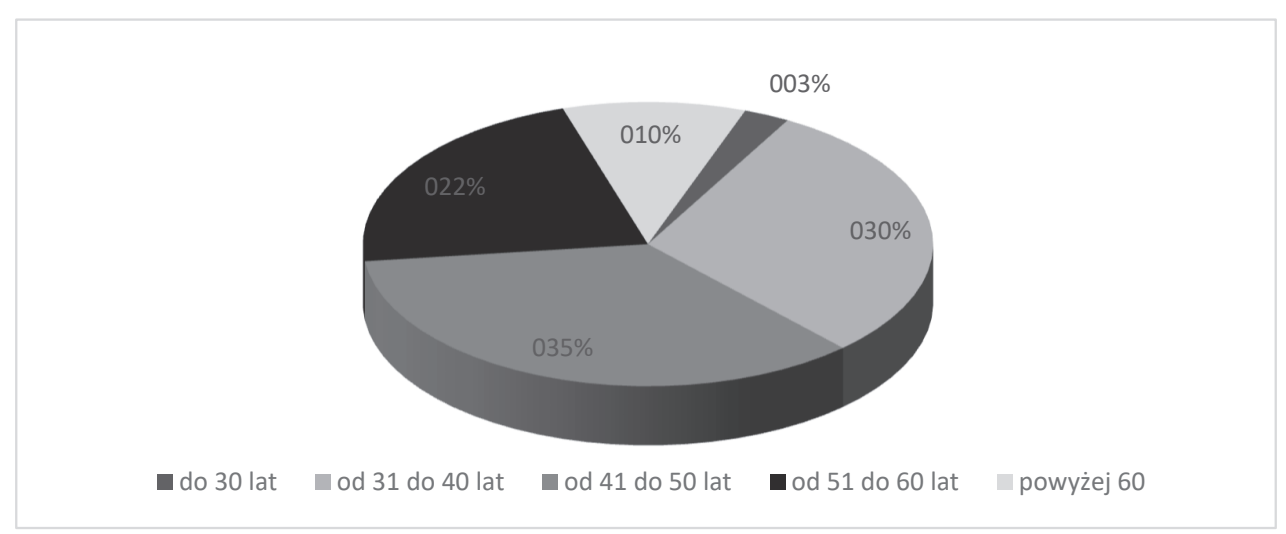

Rysunek 1. Charakterystyka respondentów ze względu na wiek $(n=77)$

Źr ódło: opracowanie własne.

Biorąc pod uwagę grupę właścicieli, 47,06\% miało powyżej 50 lat, wiek 41,18\% kształtował się w przedziale 41-50 lat, natomiast 11,76\% właścicieli miało poniżej 40 lat. W przypadku menedżerów 20,93\% badanych miało powyżej 50 lat, wiek - 30,23\% kształtował się w przedziale 41-50 lat, 44,19\% menedżerów miało pomiędzy 31 a 40 rokiem życia, natomiast 4,65\% miało poniżej 30 lat.

Wśród badanych przeważała grupa ludzi mających średnie lub wyższe wykształcenie, z czego 67,65\% właścicieli legitymowało się wykształceniem wyższym, 20,59\% - średnim, $11,76 \%$ - zawodowym. W przypadku menedżerów 72,09\% legitymowało się wykształceniem wyższym, 23,26\% średnim, 4,65\% zawodowym. 


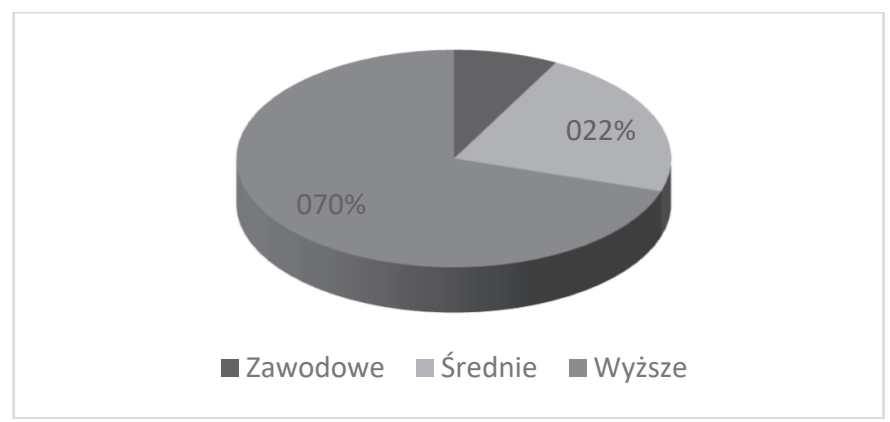

Rysunek 2. Charakterystyka respondentów ze względu na wykształcenie $(n=77)$

Źr ódło: opracowanie własne.

Determinanty zidentyfikowane w badaniach literaturowo-projektowych poddane zostały szczegółowej weryfikacji. Zebrane wyniki analizowano pod kątem wartości średnich, jednocześnie wyodrębniając te, które były oceniane przez respondentów jako ważne i kluczowe. Łącznie na tej podstawie skompilowano hierarchicznie zorganizowany, według największej istotności (najwyższej średniej), katalog deskryptów definiujących koszty jakości (rozpoznano kierunek postrzegania), (2) wyartykułowano ich miejsce i wskazano na rolę w strategii przedsiębiorstwa produkcyjnego. Szczegółowe wyniki badań opisano w dalszej części pracy.

\section{Wyniki badań własnych}

Do najważniejszych decyzji podejmowanych przez menedżerów należą działania wspierające poprawę efektywności jednostki. Osiągnięcie zamierzonych celów możliwe jest poprzez zarządzanie kosztami, także tymi związanymi z jakością. Realizacja wymaga posiadania informacji o kierunku ich postrzegania, roli oraz miejscu generowania i wysokości. Wyniki realizowanych badań utwierdzają autorów w przekonaniu, że koszty jakości można ogólnie podzielić na cztery grupy (Ciechan-Kujawa, 2005): (1) koszty odnoszące się do procesu wytwarzania wyrobu (wąskie ujęcie); (2) koszty ponoszone przez organizację; (3) koszty, które ponosi użytkownik; (4) koszty ponoszone w ciągu całego cyklu życia wyrobu przez wszystkich uczestników rynku (szerokie ujęcie). Szczegółowe dane zawarto w tabeli 2. 
Tabela 2. Miejsce i rola kosztów jakości w strategii przedsiębiorstwa produkcyjnego kierunek postrzegania

\begin{tabular}{|c|c|c|c|c|c|c|}
\hline \multirow{2}{*}{ Koszty jakości } & 1 & 2 & 3 & 4 & 5 & \multirow{2}{*}{ Średnia } \\
\hline & \multicolumn{5}{|c|}{$(\%)$} & \\
\hline $\begin{array}{l}\text { Koszty związane ze stratą przychodów } \\
\text { wynikających z utraty dotychczasowych } \\
\text { i potencjalnych klientów oraz wynikające } \\
\text { z utraty potencjalnego wzrostu obrotów } \\
\text { w wyniku niedostarczenia produktów } \\
\text { lub usług na niewłaściwym poziomie lub } \\
\text { w wyniku nieodpowiedniej reakcji na } \\
\text { potrzeby klienta }\end{array}$ & - & - & $\begin{array}{c}4,0 \\
(5,2)\end{array}$ & $\begin{array}{c}28,0 \\
(36,4)\end{array}$ & $\begin{array}{c}45,0 \\
(58,4)\end{array}$ & 4,53 \\
\hline $\begin{array}{l}\text { Wynikają z niezaspokojenia wymagań } \\
\text { stawianych jakości wyrobu przed jego } \\
\text { dostarczeniem, np. przeróbka, poprawki, } \\
\text { ponowne badania, złomowanie, }\end{array}$ & - & - & $\begin{array}{c}5,0 \\
(6,5)\end{array}$ & $\begin{array}{c}35,0 \\
(45,5)\end{array}$ & $\begin{array}{c}37,0 \\
(48,1)\end{array}$ & 4,42 \\
\hline $\begin{array}{l}\text { Stanowią koszt zaspokojenia wszystkich } \\
\text { ustalonych i założonych potrzeb klienta, } \\
\text { przy równoczesnym i prawidłowym } \\
\text { przebiegu procesu }\end{array}$ & - & - & $\begin{array}{c}5,0 \\
(6,5)\end{array}$ & $\begin{array}{c}36,0 \\
(46,8)\end{array}$ & $\begin{array}{c}36,0 \\
(46,8)\end{array}$ & 4,40 \\
\hline $\begin{array}{l}\text { Wpływają w sposób zdecydowany na } \\
\text { kształtowanie się zysku }\end{array}$ & - & $\begin{array}{c}1,0 \\
(1,3)\end{array}$ & $\begin{array}{c}5,0 \\
(6,5)\end{array}$ & $\begin{array}{c}34,0 \\
(44,2)\end{array}$ & $\begin{array}{c}37,0 \\
(48,1)\end{array}$ & 4,39 \\
\hline $\begin{array}{l}\text { Związane z prowadzeniem badań, } \\
\text { działaniami kontrolnymi i sprawdzeniami, } \\
\text { które wykonuje się w celu sprawdzenia } \\
\text { wymagań jakościowych }\end{array}$ & - & - & $\begin{array}{c}5,0 \\
(6,5)\end{array}$ & $\begin{array}{c}38,0 \\
(49,4)\end{array}$ & $\begin{array}{c}34,0 \\
(44,2)\end{array}$ & 4,38 \\
\hline $\begin{array}{l}\text { Spowodowane są zapewnieniem } \\
\text { i zabezpieczeniem zadawalającej } \\
\text { jakości }\end{array}$ & - & - & $\begin{array}{c}9,0 \\
(11,7)\end{array}$ & $\begin{array}{c}34,0 \\
(44,2)\end{array}$ & $\begin{array}{c}34,0 \\
(44,2)\end{array}$ & 4,32 \\
\hline $\begin{array}{l}\text { Nakłady bądź straty, jakie ponosi } \\
\text { przedsiębiorstwo w związku } \\
\text { z wytworzeniem i sprzedażą produktów } \\
\text { o określonym poziomie jakości }\end{array}$ & - & - & $\begin{array}{c}8,0 \\
(10,4)\end{array}$ & $\begin{array}{c}37,0 \\
(48,1)\end{array}$ & $\begin{array}{c}32,0 \\
(41,6)\end{array}$ & 4,31 \\
\hline $\begin{array}{l}\text { Wynikają z niezaspokojenia wymagań } \\
\text { stawianych jakości wyrobu po jego } \\
\text { dostarczeniu, np. koszty z tytułu } \\
\text { gwarancji i zwrotów, koszty z tytułu } \\
\text { odpowiedzialności }\end{array}$ & - & - & $\begin{array}{c}6,0 \\
(7,8)\end{array}$ & $\begin{array}{c}43,0 \\
(55,8)\end{array}$ & $\begin{array}{c}28,0 \\
(36,4)\end{array}$ & 4,29 \\
\hline $\begin{array}{l}\text { Rozpatrywane jako koszt spowodowany } \\
\text { nieprawidłowym przebiegiem procesu }\end{array}$ & - & $\begin{array}{c}1,0 \\
(1,3)\end{array}$ & $\begin{array}{c}9,0 \\
(11,7)\end{array}$ & $\begin{array}{c}35,0 \\
(45,5)\end{array}$ & $\begin{array}{c}32,0 \\
(41,6)\end{array}$ & 4,27 \\
\hline $\begin{array}{l}\text { Są to nakłady poniesione na uzyskanie } \\
\text { odpowiedniej jakości produktu } \\
\text { uzgodnionej z klientem }\end{array}$ & - & $2,0(2,6)$ & $\begin{array}{c}11,0 \\
(14,3)\end{array}$ & $\begin{array}{c}29,0 \\
(37,7)\end{array}$ & $\begin{array}{c}35,0 \\
(45,5)\end{array}$ & 4,26 \\
\hline $\begin{array}{l}\text { Koszty jakości są niezbędnym } \\
\text { instrumentem wspomagającym decyzje } \\
\text { menedżerskie i bezwzględnie powinny } \\
\text { być mierzone }\end{array}$ & - & - & $\begin{array}{c}8,0 \\
(10,4)\end{array}$ & $\begin{array}{c}42,0 \\
(54,5)\end{array}$ & $\begin{array}{c}27,0 \\
(35,1)\end{array}$ & 4,25 \\
\hline $\begin{array}{l}\text { Stanowią ważne narzędzie służące } \\
\text { dokonywaniu ocen działań } \\
\text { projakościowych }\end{array}$ & & $\begin{array}{c}2,0 \\
(2,6)\end{array}$ & $\begin{array}{c}9,0 \\
(11,7)\end{array}$ & $\begin{array}{c}35,0 \\
(45,5)\end{array}$ & $\begin{array}{c}31,0 \\
(40,3)\end{array}$ & 4,23 \\
\hline
\end{tabular}




\begin{tabular}{|c|c|c|c|c|c|c|}
\hline $\begin{array}{l}\text { Związane są z podjęciem działań } \\
\text { mających na celu uniknięcie szkód }\end{array}$ & - & $\begin{array}{l}2,0 \\
(2,6)\end{array}$ & $\begin{array}{c}11,0 \\
(14,3)\end{array}$ & $\begin{array}{c}34,0 \\
(44,2)\end{array}$ & $\begin{array}{c}30,0 \\
(39,0)\end{array}$ & 4,19 \\
\hline $\begin{array}{l}\text { Często są to koszty wynikające } \\
\text { z dostarczenia informacji lub usług, } \\
\text { które są niepotrzebne lub nieistotne, co } \\
\text { do których nie istnieją żadne wyraźne } \\
\text { ustalone wymagania }\end{array}$ & $\begin{array}{c}1,0 \\
(1,3)\end{array}$ & $\begin{array}{c}1,0 \\
(1,3)\end{array}$ & $\begin{array}{c}10,0 \\
(13,0)\end{array}$ & $\begin{array}{c}36,0 \\
(46,8)\end{array}$ & $\begin{array}{c}29,0 \\
(37,7)\end{array}$ & 4,18 \\
\hline $\begin{array}{l}\text { Są podstawą do podejmowania decyzji } \\
\text { o charakterze strategicznym }\end{array}$ & - & - & $\begin{array}{c}14,0 \\
(18,2)\end{array}$ & $\begin{array}{c}36,0 \\
(46,8)\end{array}$ & $\begin{array}{c}27,0 \\
(35,1)\end{array}$ & 4,17 \\
\hline $\begin{array}{l}\text { Wyrażają cel sterowania jakością, } \\
\text { który sprowadza się do takiego doboru } \\
\text { struktury nakładów, przy której suma } \\
\text { kosztów poniesiona na jakość będzie } \\
\text { najmniejsza }\end{array}$ & - & $\begin{array}{c}2,0 \\
(2,6)\end{array}$ & $\begin{array}{c}13,0 \\
(16,9)\end{array}$ & $\begin{array}{c}33,0 \\
(42,9)\end{array}$ & $\begin{array}{c}29,0 \\
(37,7)\end{array}$ & 4,16 \\
\hline $\begin{array}{l}\text { Dostarczają informacji odnoszących się } \\
\text { do stopnia realizacji systemu sterowania } \\
\text { jakością w przedsiębiorstwie }\end{array}$ & - & $\begin{array}{c}1,0 \\
(1,3)\end{array}$ & $\begin{array}{c}15,0 \\
(19,5)\end{array}$ & $\begin{array}{c}34,0 \\
(44,2)\end{array}$ & $\begin{array}{c}27,0 \\
(35,1)\end{array}$ & 4,13 \\
\hline $\begin{array}{l}\text { Są instrumentem poprawy jakości } \\
\text { i efektywności gospodarowania }\end{array}$ & - & $3,0(3,9)$ & $\begin{array}{c}13,0 \\
(16,9)\end{array}$ & $\begin{array}{c}32,0 \\
(41,6)\end{array}$ & $\begin{array}{c}29,0 \\
(37,7)\end{array}$ & 4,13 \\
\hline $\begin{array}{l}\text { Powinny wpływać na wyobraźnię } \\
\text { kierownictw i wszystkich pracowników }\end{array}$ & - & - & $\begin{array}{c}14,0 \\
(18,2)\end{array}$ & $\begin{array}{c}40,0 \\
(51,9)\end{array}$ & $\begin{array}{c}23,0 \\
(29,9)\end{array}$ & 4,12 \\
\hline $\begin{array}{l}\text { Stanowią ważne narzędzie zarządzania } \\
\text { przedsiębiorstwem }\end{array}$ & - & - & $\begin{array}{c}18,0 \\
(23,4)\end{array}$ & $\begin{array}{c}34,0 \\
(44,2)\end{array}$ & $\begin{array}{c}25,0 \\
(32,5)\end{array}$ & 4,09 \\
\hline $\begin{array}{l}\text { Są narzędziem służącym ocenie } \\
\text { przedsięwzięć projakościowych } \\
\text { w przedsiębiorstwie }\end{array}$ & - & - & $\begin{array}{c}14,0 \\
(18,2)\end{array}$ & $\begin{array}{c}42,0 \\
(54,5)\end{array}$ & $\begin{array}{c}21,0 \\
(27,3)\end{array}$ & 4,09 \\
\hline $\begin{array}{l}\text { Stanowią narzędzie zarządzania } \\
\text { przyszłością przedsiębiorstwa }\end{array}$ & $\begin{array}{c}1,0 \\
(1,3)\end{array}$ & $\begin{array}{c}1,0 \\
(1,3)\end{array}$ & $\begin{array}{c}15,0 \\
(19,5)\end{array}$ & $\begin{array}{c}33,0 \\
(42,9)\end{array}$ & $\begin{array}{c}27,0 \\
(35,1)\end{array}$ & 4,09 \\
\hline $\begin{array}{l}\text { Pełnią rolę narzędzia przydatnego } \\
\text { w wyznaczaniu optymalnego poziomu } \\
\text { jakości wyrobów }\end{array}$ & $1,0(1,3$ & - & $\begin{array}{c}17,0 \\
(22,1)\end{array}$ & $\begin{array}{c}35,0 \\
(45,5)\end{array}$ & $\begin{array}{c}24,0 \\
(31,2)\end{array}$ & 4,05 \\
\hline
\end{tabular}

Źr ódło: opracowanie własne.

Badani menedżerowie w coraz większym stopniu doceniają rolę klienta w realizacji celów strategicznych i operacyjnych przedsiębiorstw, a w szczególności w kreowaniu ich wartości. Dlatego w ramach rachunkowości (zarówno tej finansowej, jak i zarządczej) pomiar znaczenia klientów dla przedsiębiorstw powinien odbywać się przez pryzmat ich rentowności. Źródłem informacji o kosztach klientów, które można z powodzeniem wykorzystać w rachunku kosztów docelowych, jest prowadzony przez przedsiębiorstwo rachunek kosztów klienta. Rachunek kosztów docelowych zintegrowany z rachunkiem kosztów klienta ukierunkowany jest na wyznaczanie kosztu docelowego i takie zaprojektowanie działań w ramach relacji z klientami (poczynając od pozyskania klienta, a kończąc na minimalizacji negatywnych skutków odejścia klienta), które umożliwią redukcję bieżących kosztów klienta do poziomu kosztów docelowych. Tak sformułowany cel w powiązaniu z działaniami podejmowanymi przez przedsiębiorstwo w ramach rachunku kosztów klienta pozwala na poprawę pozycji przedsiębiorstwa pod względem kosztów zarówno dla obecnych, jak i nowych klientów. Za- 
uważa się zatem, że rachunek kosztów docelowych klienta jest nie tylko rachunkiem kosztów, ale także, a nawet przede wszystkim metodą strategicznego zarządzania kosztami jakości klienta. Wskazuje się zatem na koszty związane ze stratą przychodów wynikających $\mathrm{z}$ utraty dotychczasowych i potencjalnych klientów oraz wynikające $\mathrm{z}$ utraty potencjalnego wzrostu obrotów w wyniku niedostarczenia produktów lub usług na niewłaściwym poziomie lub w wyniku nieodpowiedniej reakcji na potrzeby klienta (średnia ocena 4,$53 ; 58,4 \%$ wskazań dla oceny 5 punktów). Wynikają z niezaspokojenia wymagań stawianych jakości wyrobu przed jego dostarczeniem, np. przeróbka, poprawki, ponowne badania, złomowanie (średnia ocena 4,$42 ; 48,1 \%$ wskazań dla oceny 5 punktów). Stanowią koszt zaspokojenia wszystkich ustalonych i założonych potrzeb klienta, przy równoczesnym i prawidłowym przebiegu procesu (średnia ocena 4,40; 46,8\% wskazań dla oceny 5 punktów). Na szczególną uwagę zasługuje zatem zdolność pozyskiwania informacji zwrotnej od klienta i oczekiwań użytkownika wyrobu, sposobu komunikowania się z nabywcą, prezentowania się produktu na tle konkurencji i możliwości jego doskonalenia. Idea integracji kosztów jakości i marketingu znajduje wyraz w normie ISO 9001 (PN-EN ISO 9001:2015), gdzie w modelu zarządzania jakością, którego podstawą jest proces, klient jest obecny zarówno po stronie wymagań, jak i po stronie zadowolenia (rezultatu). Producent oferuje na rynku w odpowiednim czasie produkt o określonych właściwościach. Przy czym dla klienta ważny jest nie tyle sam produkt, ile wartość, jaką otrzymuje od jego dostawcy.

Doświadczenie, rozwój nowych metod zarządzania oraz lepsza organizacja pozwalają producentowi zmniejszyć nakłady związane z kosztowniejszą technologią wytwarzania. Może on zatem produkować dobra o wyższej jakości przy tych samych kosztach; właśnie tego oczekuje się od niego w świetle wzrastających wymagań jakościowych nabywców. Wyścig między żądaniem przez konsumenta wyższego poziomu jakości zaprojektowanego wyrobu, mającego jednak tę samą cenę, oraz dążeniem wytwórcy do produkcji przy niezwiększonych kosztach nie ustaje (Ettinger, Sittig, 1970, s. 53-56). Odrębnym zagadnieniem są związki pomiędzy poziomem jakości wykonania produktu a przychodami, kosztami i zyskiem przedsiębiorstwa. Wzrost jakości wykonania produktów zwykle oznacza wzrost sprzedaży i wyższe przychody. Przeprowadzone rozważania nasuwają wniosek, że wytwarzanie produktów o optymalnej jakości projektu i wykonania oznacza osiąganie najwyższego zysku, co ewidentnie potwierdzają wyniki prowadzonych badań. Zdaniem respondentów koszty jakości wpływają w sposób zdecydowany na kształtowanie się zysku (średnia ocena 4,39; 48,1\% wskazań dla oceny 5 punktów). Uzyskane wyniki jednoznacznie unaoczniają, że firmy sprzedające wyroby i świadczące usługi na wysokim poziomie jakości są generalnie bardziej rentowne niż te, które oferują wyroby i usługi na poziomie niskim ${ }^{5}$. Należy jednak podkreślić, że zainteresowanie producenta poprawą jakości produktu nastąpi tylko wówczas, gdy wzrost korzyści (m.in. zysku) jest wyższy od przyrostu nakładów i kosztów związanych z podwyższeniem poziomu cech jakościowych, a zatem gdy tendencja do poprawy relacji między przyrostem poziomu jakości a przyrostem nakładów i kosztów jest silniejsza od obniżki wydatków, na celowość redukcji których wskazuje np. miernik rentowności.

\footnotetext{
${ }^{5}$ Zauważa się istotny wzrost wskaźnika ROI i zysku netto wraz ze wzrostem jakości produktu.
} 
Tradycyjna koncepcja zakłada, iż wysoki poziom jakości wykonania związany jest ze znacznymi kosztami jego uzyskania. Prowadzi to do przekonania, że dobra jakość może być osiągnięta jedynie poprzez nasiloną prewencję i ocenę jakości, co wymaga zatrudnienia wielu specjalistów. Jednak dobrą jakość można uzyskać również dzięki prowadzeniu badań, działaniom kontrolnym i sprawdzeniom, które wykonuje się w celu weryfikacji wymagań jakościowych (średnia ocena 4,$38 ; 44,2 \%$ wskazań dla oceny 5 punktów). Tym samym koszty jakości implikowane są zapewnieniem i zabezpieczeniem zadawalającej jakości (średnia ocena 4,32; $44,2 \%$ wskazań dla oceny 5 punktów). Innymi słowy koszty jakości to nakłady bądź straty, jakie ponosi przedsiębiorstwo w związku z wytworzeniem i sprzedażą produktów o określonym poziomie jakości (średnia ocena 4,31; 41,6\% wskazań dla oceny 5 punktów).

Poziom jakości wyrażający się w uzyskanym przez wytwórcę standardzie zarządzania i wykonania wyrobu wpływa na wielkość wyniku finansowego pośrednio i bezpośrednio. Pośrednio - przez ułatwienie ekspansji rynkowej, rozszerzenie rynków zbytu, kształtowanie przyzwyczajeń nabywcy do kupowania wyrobów danego producenta. Bezpośrednio natomiast poprzez wpływ na wysokość ponoszonych kosztów operacyjnych oraz na wielkość strat spowodowanych wadliwością wewnętrzną i zewnętrzną. Dlatego w prezentowanym ujęciu koszty jakości utożsamia się z brakiem zaspokojenia wymagań stawianych jakości wyrobu po jego dostarczeniu (średnia ocena 4,29; 36,4\% wskazań dla oceny 5 punktów). W opozycji do artykułowanej definicji wskazano, że koszty jakości są to nakłady poniesione na uzyskanie odpowiedniej jakości produktu uzgodnionej z klientem (średnia ocena 4,26; 45,5\% wskazań dla oceny 5 punktów).

Jakość wykonania wyrobów kształtowana jest w sekwencji procesów, z których każdy jest zmienny. Nawet w procesie o dużej stabilności powstają, w wyniku działania czynników losowych, wyroby różniące się parametrami. W kontekście powyższego niekiedy koszty jakości rozpatrywane są jako koszt spowodowany nieprawidłowym przebiegiem procesu (średnia ocena 4,27; 41,6\% wskazań dla oceny 5 punktów).

Punkt wyjścia w procesie podejmowania decyzji stanowi precyzyjne określenie celów projakościowych. Ma to na celu ukazanie zalet i wad poszczególnych rozwiązań, czyli kosztów jakości, jakie pociągają za sobą oraz możliwych do wygenerowania korzyści, zarówno finansowych, jak i pozafinansowych. Koszty jakości należą do podstawowych kryteriów wyboru decyzji. Ich ranga jako elementu decyzyjnego wynika stąd, że wprawdzie nie można uniknąć ponoszenia kosztów w związku ze wzrostem jakości, lecz można je minimalizować. Wyniki badań wskazują jednoznacznie, że koszty jakości są niezbędnym instrumentem wspomagającym decyzje menedżerskie ${ }^{6} \mathrm{i}$ bezwzględnie powinny być mierzone (średnia ocena 4,25; 35,1\% wskazań dla oceny 5 punktów). Tym samym stanowią ważne narzędzie służące dokonywaniu ocen działań projakościowych (średnia ocena 4,23; 40,3\% wskazań dla oceny 5 punktów).

Do kosztów jakości zaliczane są koszty prewencji, kontroli, inspekcji i badań. Są to np. koszty walidacji projektów, koszty utrzymania przyrządów kontrolno-pomiarowych, koszty ponoszone na analizę przyczyn powstawania niezgodności czy też koszty kontroli dostaw $i$ audytów wewnętrznych. Według badanych przedsiębiorstw związane są z podjęciem działań mających na celu uniknięcie szkód (średnia ocena 4,19;39,0\% wskazań dla oceny 5

${ }^{6}$ Są podstawą do podejmowania decyzji o charakterze strategicznym (średnia ocena 4,17; 35,1\% wskazań dla oceny 5 punktów). 
punktów). Przy czym zwraca się uwagę na koszty wynikające z dostarczenia zasobów, informacji lub usług, które są niepotrzebne lub nieistotne, co do których nie istnieją żadne wyraźne ustalone wymagania (średnia ocena 4,$18 ; 37,7 \%$ wskazań dla oceny 5 punktów). W tym podejściu uwypuklono istotę kosztów utraconych możliwości stanowiących koszty zabezpieczenia się na przyszłość powstające z zaabsorbowania kierownictwa problemami przeszłości oraz nie zwrócenia uwagi na związek bieżącej jakości z przyszłymi zyskami.

Istotną rolę pełnią koszty związane z profilaktyką projakościową. W przedsiębiorstwach, dla których poprawa jakości ich wyrobów jest procesem ciągłym, stanowią one większość ogółu kosztów jakości. Większa dbałość o jakość produktu już na etapie jego projektowania, udoskonalanie metod produkcji, prowadzi w rezultacie do redukcji kosztów związanych z oceną i wadliwością wyrobów. Wraz ze wzrostem wydatków na profilaktykę i ocenę następuje spadek liczby braków i związane z tym zmniejszenie kosztów braku zgodności. W artykułowanym podejściu koszty jakości wyrażają cel sterowania jakością, który sprowadza się do takiego doboru struktury nakładów, przy której suma kosztów poniesiona na jakość będzie najmniejsza (średnia ocena 4,16;37,7\% wskazań dla oceny 5 punktów). Dostarczają informacji odnoszących się do stopnia realizacji systemu sterowania jakością w przedsiębiorstwie (średnia ocena 4,13;35,1\% wskazań dla oceny 5 punktów).

Wysoką jakość można uzyskać również dzięki zaangażowaniu wszystkich pracowników, począwszy od najwyższego kierownictwa, a skończywszy na pracownikach wykonawczych $^{7}$. We współczesnym zarządzaniu jakością uczestnictwo wszystkich pracowników jest nie tylko pożądane, ale wręcz obligatoryjne. Koncepcja ta nie wymaga zatrudnienia wielu specjalistów. W zamian za to każdy pracownik firmy powinien być zorientowany na jakość i starać się eliminować każdy problem, z jakim może spotkać się w swojej pracy. W rezultacie oznacza to redukcję kosztów przy jednoczesnym wzroście poziomu jakości produktu. W związku z powyższym koszty jakości stanowią ważne narzędzie zarządzania przedsiębiorstwem (średnia ocena 4,09;32,5\% wskazań dla oceny 5 punktów) ${ }^{8}$. Są instrumentem poprawy jakości i efektywności gospodarowania (średnia ocena 4,13; 37,7\% wskazań dla oceny 5 punktów). Stanowią narzędzie służące ocenie przedsięwzięć projakościowych w przedsiębiorstwie z jednej strony (średnia ocena 4,$09 ; 27,3 \%$ wskazań dla oceny 5 punktów), z drugiej zaś pełnią rolę narzędzia przydatnego w wyznaczaniu optymalnego poziomu jakości wyrobów (średnia ocena 4,05; 31,2\% wskazań dla oceny 5 punktów).

\section{Dyskusja i wnioski}

Wyniki badań predysponują autorów do stwierdzenia, że koszty jakości traktuje się jako instrument służący do oceny efektywności systemu jakości. Zwrócono uwagę na koszty błędów (wewnętrznych i zewnętrznych), koszty oceny oraz koszty prewencji (zapobiegania)9.

\footnotetext{
${ }^{7}$ Postuluje się zatem, że koszty jakości powinny wpływać na wyobraźnię kierownictw i wszystkich pracowników (średnia ocena 4,$12 ; 29,9 \%$ wskazań dla oceny 5 punktów).

${ }^{8}$ Wskazuje się na ich rolę w zarządzaniu przyszłością przedsiębiorstwa (średnia ocena 4,13;35,1\% wskazań dla oceny 5 punktów).

${ }^{9}$ Do kosztów prewencji zaliczono m.in. planowanie jakości, kontrole procesów, zarządzanie i rozwój systemu jakości, co odzwierciedla podejście wielokrotnie uwypuklane przez A. Feigenbaum. Szerzej: Zymonik, 2003.
} 
W kontekście powyższego wyartykułowano koszty działalności zapobiegawczej, które obejmują nakłady producenta poniesione na poprawę jakości wytwarzanych produktów, zmniejszenie ilości braków i wielkości ponoszonych strat z tytułu niskiej jakości oraz zapobieganie powstawaniu w czasie procesu produkcji złych jakościowo wyrobów, bez znacznego zwiększenia kosztów kontroli jakości.

Koszty jakości rozpatrywane są w wąskiej i szerokiej perspektywie. Koszty, które ponosi przedsiębiorstwo w związku z wytwarzaniem produktów (zaczynając od badań i rozwoju, przez projektowanie, wytwarzanie, marketing, dystrybucję, a kończąc na obsłudze klienta), odnosi się do wąskiego ujęcia. Natomiast w szerokiej perspektywie zwraca się uwagę na tzw. społeczne koszty jakości, dotyczące kosztów w całym cyklu życia produktów, ponoszonych nie tylko w samym przedsiębiorstwie, ale również poza jego obszarem, przez klientów, pośredników czy sprzedawców (Kokot-Stępień, 2014, s. 83-92). W wyniku prowadzonych badań dowiedziono, że koszty jakości mogą powstawać w różnych obszarach działalności przedsiębiorstwa, m.in. środowiskowym. Wyróżnia się tutaj straty ekologiczne spowodowane zanieczyszczeniem środowiska, straty wynikające z niewłaściwej utylizacji odpadów, straty powstałe z wyczerpania się rzadkich zasobów naturalnych (Nowak, Wierzbiński, 2010). Zwrócono uwagę na koszty, które wiążą się z obiektywnymi dowodami wymaganej przez odbiorców jakości. Są to koszty ponoszone przez producenta, m.in. na projektowanie i wdrażanie certyfikowanych systemów jakości, zaprezentowanie swoich wyrobów na rynku oraz przeprowadzenie oceny ich jakości przez niezależne jednostki badawcze.

Wyniki prowadzonych analiz pozwalają postulować o kosztach jakości w odniesieniu do kosztów oceny jakości, które uwzględniają koszty dokonywania pomiarów, innych form kontroli jakości surowców, półproduktów i wyrobów finalnych, w celu wyeliminowania przyczyn niskiej jakości w jak najwcześniejszym stadium procesu produkcji. Zwrócono uwagę na straty na brakach wewnętrznych, czyli takie, które zostały ujawnione w ramach przedsiębiorstwa, oraz na straty, które zostały odkryte przez odbiorcę i muszą być przez producenta w ramach gwarancji lub rękojmi zrekompensowane poprzez wymianę na produkt bez wad, zwrot wartości produktu lub jego naprawę (braki zewnętrzne).

Rekapitulując, należy doprecyzować, że koszty jakości to nie tylko koszty błędów, ale również koszty działań, które mają zapobiegać powstawaniu tych błędów. Prowadzone badania wskazują jednoznacznie, że koszty jakości dzielone są na kilka kategorii związanych głównie z prewencją, oceną, badaniami i kontrolą (koszty te uznawane są za koszty zgodności z wymaganiami jakościowymi) oraz błędami (koszty niezgodności), co jest zbieżne z poglądami prezentowanymi przez Z. Zymonik (Zając, 2014, s. 166). Jakkolwiek w literaturze brak jest jednolitego podziału kosztów jakości, co wiąże się z różnorodnością działań związanych z jakością i ich powiązań z procesem produkcji, to wyniki badań utwierdzają autorów w przekonaniu, że także wśród praktyków zarządzania istnieje wiele modeli i metod ich podziału. Najważniejszym kryterium podziału kosztów związanych z jakością jest dostępność - większość stanowią koszty ukryte (hidden quality costs), a tych widzialnych i łatwo mierzalnych (measured quality costs) jest stosunkowo niewiele.

Różni autorzy zajmujący się problematyką kosztów jakości, podobnie jak przedstawiciele badanych firm, odmiennie próbują wyjaśnić i określić miejsce i rolę kosztów jakości w strategii ich przedsiębiorstwa produkcyjnego. Zwraca się uwagę na strategie kosztowe ukierun- 
kowujące wszystkie działania przedsiębiorstwa na jedyny główny cel, jakim jest minimalizacja kosztów całkowitych. Strategie kosztowe opierają się na założeniu, że najlepszą pozycję konkurencyjną uzyskują te firmy, które mają najniższe koszty. Motywem przewodnim strategii przodownictwa kosztowego staje się niski koszt wytwarzania w porównaniu z konkurentami, jednak nie można pomijać jakości i poziomu obsługi klienta; należy pamiętać, aby klientom nie proponować produktów niższej jakości. Wobec czego w praktyce gospodarczej gromadzenie informacji o kosztach jakości niejednokrotnie staje się celem, a nie środkiem do osiągnięcia celów. Koszty jakości, jako skuteczny i efektywny instrument w kreowaniu strategii przedsiębiorstwa, muszą być nie tylko prawidłowo mierzone, ale także właściwie analizowane pod kątem rozeznania źródeł ich powstania, przyczyn i skutków. Rachunek kosztów jakości jest pomocny w procesie planowania polityki projakościowej przedsiębiorstwa. Umożliwia opracowanie strategii obniżenia poziomu kosztów produkcji przy jednoczesnym utrzymaniu lub wzroście poziomu jakości wyrobów. Rachunek kosztów dostarcza niezbędnych informacji w procesach decyzyjnych o rozpoczęciu produkcji nowego wyrobu lub ulepszeniu dotychczas funkcjonującego na rynku. Odpowiednie wdrożenie, dogłębne przeprowadzenie analizy i interpretacji wyników daje szansę poprawy efektywności i wydajności działania oraz redukcję wadliwej jakości. Analiza kosztów jakości pozwala na uzyskanie informacji dotyczących efektywności zarządzania, opracowanie priorytetów w podejmowaniu działań oraz określenie obszarów występowania problemów na co wskazują badane przedsiębiorstwa.

W ich opinii koszty jakości obejmują zarówno koszty niezgodności, jak i zgodności, co uwypuklono także w definicji zaproponowanej przez P. Crosby'ego (Karaszewski, Skrzypczyńska, 2013, s. 51). Podkreślono znaczenie pewności, że klient otrzymywać będzie tylko te produkty, które zostały wykonane zgodnie ze specyfikacją wymagań i wedle jego oczekiwań, co wskazuje na utożsamianie kosztów jakości adekwatnie do kierunku wskazanego przez F. Nixona (1974, s. 38). W toku realizowanych badań zwrócono uwagę, że wzrastające nakłady na zapobieganie nieprawidłowościom wykonania powinny powodować spadek kosztów z tytułu strat ponoszonych przy produkcji wyrobów wadliwych, a łącznie przyczyniać się do zapewnienia optymalnego poziomu jakości, obniżającego koszty własne wytworzenia, co podkreśla w swojej pracy K. Lisiecka (2002, s. 281-282). Podobnie jak w ujęciu T. Borysa (2012, s. 7-23), w opinii respondentów, na koszty jakości składają się ponoszone nakłady lub utracone korzyści jako skutek niedoskonałości działania (Borys, Rogala, 2011). A zatem koszty jakości obejmują koszty niskiego poziomu jakości, koszty badania poziomu jakości i koszty przedsięwzięć zapobiegawczych.

Rola kosztów jakości wydaje się być bardzo cenna w całym systemie funkcjonowania przedsiębiorstwa produkcyjnego. Umożliwiają bowiem stworzenie takich rozwiązań w strukturze nakładów, przy których straty i koszty ponoszone na rozwiązania projakościowe są najmniejsze. Daje tą możliwość optymalizacja produkcji. Koszty jakości odgrywają dużą i ważną rolę w procesie podejmowania decyzji w przedsiębiorstwie. Wskazują miejsca powstawania wad, możliwości redukcji kosztów, poprawę produktywności oraz wydajności pracy. Odpowiednie określenie oraz zlokalizowanie kosztów niezgodności daje szansę na ich zminimalizowanie poprzez wprowadzenie odpowiednich działań korygujących. Podsumowując trzeba podkreślić, że z punktu widzenia przedsiębiorstwa, które dąży do zwiększenia 
efektywności systemów zarządzania, poprawy jakości i optymalizacji kosztów z nią związanych, staje się właściwe zidentyfikowanie ich miejsc powstawania, tak by ewidencjonowane były według rzeczywistych miejsc powstawania, a nie miejsc ujawniania.

Przedstawione definicje kosztów jakości potwierdzają brak jednolitej wersji tego pojęcia. Różnorodność jest skutkiem stosowania różnych podejść do jakości przez badaczy reprezentujących nauki społeczne. Wydaje się, że elementem łączącym wszystkie definicje w sposób bezpośredni lub pośredni jest klient i jego postrzeganie jakości zakupionego produktu lub wyświadczonej usługi. Koncepcja wartości dla klienta spójna jest z podejściem, w którym stosuje się pojęcie użyteczności produktu z punktu widzenia klienta, kierującego się dwoma podstawowymi kryteriami: korzyściami, jakie może mieć z nabytego produktu, oraz kosztami, jakie musi ponieść w związku z nabywanym produktem.

Wspólne cechy charakterystyczne to także aspekt niedoskonałości, wady produktów czy bezbłędne działanie jako cel każdej organizacji. Wielu autorów traktuje koszty jakości jako nakłady, które są ponoszone na osiągnięcie zakładanego poziomu jakości. Do istotnych różnic w definiowaniu kosztów jakości należą podejścia, które wskazują na koszty jakości jako ważny wskaźnik diagnostyczny czy finansowe kryterium wyrażające istotne informacje, aspekt rozwoju systemów zarządzania jakością oraz stratę. Różnice odnoszą się zarówno do zakresu, jak i do treści kosztów.

\section{Podsumowanie}

W ostatnich dekadach pojawiła się orientacja na jakość, polegająca na wdrażaniu systemów zarządzania jakością i stosowaniu metody zarządzania przez jakość - TQM. Tylko jakość rozumiana totalnie jest najskuteczniejszym instrumentem osiągania przewag konkurencyjnych nad rynkowymi rywalami. Niemniej jednak należy pamiętać, że do realizacji celów jakościowych przedsiębiorstwa i wynikających z nich zadań konieczne jest dysponowanie odpowiednią wiedzą dotyczącą możliwości wykorzystania oraz oceny przydatności zasad, metod i narzędzi zarządzania jakością. W procesie planowania polityki projakościowej przedsiębiorstwa pomocny jest rachunek kosztów jakości. Jest cennym narzędziem w procesie określenia celów i kosztów jakości w kolejnych okresach funkcjonowania przedsiębiorstwa. Rachunek kosztów jakości dostarcza niezbędnych informacji w procesach decyzyjnych o rozpoczęciu produkcji nowego wyrobu lub ulepszeniu dotychczas funkcjonującego na rynku. Odpowiednie wdrożenie, dogłębne przeprowadzenie analizy i interpretacji wyników, przy czynnym udziale działu kierowniczego przedsiębiorstwa, daje szansę poprawy efektywności i wydajności działania oraz redukcję wadliwej jakości (Zając, 2014, s. 183).

W pracy rozpoznano kierunek postrzegania kosztów jakości. Dookreślono ich miejsce i rolę w strategii przedsiębiorstwa produkcyjnego. Badania odniesiono do producentów części i podzespołów maszyn rolniczych przeznaczonych na pierwszy montaż. Podkreślono znaczenie kosztów jakości z perspektywy nauk o zarządzaniu i jakości (warstwa teoretyczna). Wskazano na determinanty odnoszące się istotnie do treści i zakresu prowadzonych badań. Na tej podstawie skompilowano model badawczy, który poddano weryfikacji.

Rekomendacje, będące rezultatem prowadzonych przez autorów wywodów teoretycznych oraz realizowane postępowanie badawcze, stanowią istotną bazę wiedzy, która upoważ- 
nia autorów do stwierdzenia, że poddane badaniu przedsiębiorstwa produkcyjne działające w sektorze maszyn rolniczych wykazują stosunkowo duże rozpoznanie w zakresie rachunku kosztów jakości. Ponadto należy zauważyć, że model badawczy powstały w wyniku dyskusji eksperckiej pokrywa się z kierunkiem postrzegania kosztów jakości, z jednej strony przez wybranych badaczy (naukowców), z drugiej zaś przez badane przedsiębiorstwa. Zauważa się dużą analogiczność deskryptów zaakcentowanych w teoretycznym modelu badawczym i badaniu zasadniczym (koincydencja badawcza). Eksperci wykazali się zatem dużym poziomem wiedzy i zdolności formułowania definicji, co dodatkowo uwypukla walory badania eksperckiego i związanego z tym doboru celowego.

Jakkolwiek poddane ocenie, wyartykułowane w ramach badań literaturowo-projektowych, determinanty nie wyczerpują omawianej problematyki, to należy podkreślić, że stanowią istotne przestrzenie zarządzania jakością, i jako takie mogą stanowić podstawę dalszych prac badawczych ${ }^{10}$.

\section{Bibliografia}

Abernethy, M. A., Guthrie, C. H. (1994). An empirical assessment of the „fit” between strategy and management information system design. Accounting \& Finance, 34(2), 49-66. DOI: 10.1111/j.1467-629X.1994. tb00269.x.

Abernethy, M. A., Lillis, A. M. (1995). The impact of manufacturing flexibility on management control system design. Accounting, Organizations and Society, 20(4), 241-258. DOI: 10.1016/0361-3682(94) E0014-L.

Agbejule, A. (2005). The relationship between management accounting systems and perceived environmental uncertainty on managerial performance: A research note. Accounting and Business Research, 35(4), 295-305. DOI: $10.1080 / 00014788.2005 .9729996$.

Baldegger, R. J. (2012), Management in a Dynamic Environment. Concepts, Methods and Tools. Wiesbaden: Gabler Verlag, Springer Fachmedien. ISBN 9783834937483.

Borys, T. (2012). Interdyscyplinarność nauk o jakości. Zarządzanie i Finanse, 10, 3, 1, 7-23.

Borys, T., Rogala, P. (2011). Doskonalenie sformalizowanych systemów zarządzania. Warszawa: Difin. ISBN 9788376415512.

Bouwens, J., Abernethy, M. A. (2000). The consequences of customization on management accounting system design. Accounting, Organizations and Society, 25(3), 221-241. DOI: 10.1016/S0361-3682(99)00043-4.

Brown, V. R., Paulus, P. B. (2002). Making group brainstorming more effective: Recommendations from an associative memory perspective. Current Directions in Psychological Science, 11, 208-212. DOI: $10.1111 / 1467-8721.00202$.

Burnes, B. (2000). Managing Change. A Strategic Approach to Organisational Dynamics. Wiesbaden: Pitman Publishing. ISBN 9781292156040.

Chenhall, R. H. (2003). Management control systems design within its organizational context: Findings from contingency-based research and directions for the future. Accounting, Organizations and Society, 28(23), 127-168. DOI: 10.1016/S0361-3682(01)00027-7.

Chodyński, A. (2000). Projakościowe zarządzanie rozwojem produkcji w przedsiębiorstwie. Bielsko-Biała: Wyższa Szkoła Ekonomiczno-Humanistyczna ISBN 8391350916.

Ciechan-Kujawa, M. (2005). Rachunek kosztów jakości. Wykorzystanie w zarządzaniu przedsiębiorstwem. Kraków: Oficyna Ekonomiczna. ISBN 83-89355-68-X.

Ettinger, J., Sittig, J. (1984). Lepsza jakość - większe efekty, Warszawa: WNT.

Gupta, A. K., Govindarajan, V. (1984). Business unit strategy, managerial characteristics, and business unit effectiveness at strategy implementation. Academy of Management Journal, 27(1), 25-41. DOI: $10.5465 / 255955$.

${ }^{10}$ Przedmiotem kolejnych opracowań autorów będą badania dotyczące efektów analizy kosztów jakości w strategii przedsiębiorstw produkcyjnych oraz działań ujmowanych w strategii kosztów jakości. 
Hall, J. A. (ed.) (2011). Accounting Information Systems. South Western: Cengage Learning, Mason. ISBN 1337619205.

Harrington, H. J. (1987). Poor - Quality Cost, New York and Basel Milwaukee: Marcel Dakker Inc., ASQC Quality Press. DOI: 10.1002/qre.4680030420.

Hoque, Z. (2011). The relations among competition, delegation, management accounting systems change and performance: A path model. Advances in Accounting, 27(2), 266-277. DOI: doi.org/10.1016/j. adiac.2011.05.006.

Huefner. R. J., Largay. J.A. (2008). The role of accounting information in revenue management. Business Horizons, 51(3), 245-255. DOI: 10.1016/j.bushor.2008.01.013.

Jespersen, K., Bysted, R. (2016). Implementing new product development: A study of personal characteristics among managers. International Journal of Innovation Management, 20(3). DOI: 10.1142/ S1363919616500432.

Juran, J. M., Gryna, F. M. (1974). Jakość, projektowanie, analiza. Warszawa: WNT.

Karaszewski, R. (2001). TQM teoria i praktyka, Toruń: TNOiK. ISBN 8372850313.

Karaszewski, R., Skrzypczyńska, K. (2013). Zarządzanie jakościa. Toruń: Wydawnictwo „Dom Organizatora". ISBN

Kister, A. (2005). Zarządzanie kosztami jakości. Sposób na poprawę efektywności. Kraków: Oficyna Ekonomiczna. ISBN 83-89355-70-1.

Kokot-Stępień, P. (2004). Rachunek kosztów jakości instrumentem controllingu w zakresie zarządzania jakością. Zeszyty Naukowe Uniwersytetu Szczecińskiego. Finanse, Rynki Finansowe, Ubezpieczenia, 67, 83-92.

Li, D. Y., Liu, J. (2014). Dynamic capabilities, environmental dynamism, and competitive advantage: Evidence from China. Journal of Business Research, 67(1), 2793-2799.

Lisiecka, K. (1999). Koszty zapewnienia jakości a ekonomika jakości. Problemy teorii i dylematy praktyki. Problemy Jakości, 2.

Lisiecka, K. (2000). Koszty jakości. W: J. Bagiński (red.), Menedżer jakości: jakość, środowisko, bezpieczeństwo. Warszawa: Oficyna Wydawnicza Politechniki Warszawskiej. ISBN 8372074798.

Lisiecka, K. (2002). Kreowanie jakości: Uwarunkowania - strategie - techniki. Prace Naukowe Akademii Ekonomicznej w Katowicach, 352, 281-282.

Masser, W. J. (1957). The Quality Management and Quality Costs. Quality Control in India, 14, 5-8;

Mia, L., Chenhall, R. H. (1994). The usefulness of management accounting systems, functional differentiation and managerial effectiveness. Accounting, Organizations and Society, 19(1), 1-13. DOI: 10.1016/03613682(94)90010-8.

Mia, L., Patiar, A. (2001). The use of management accounting systems in hotels: An exploratory study. International Journal of Hospitality Management, 20(2), 111-128. DOI: 10.1016/S0278-4319(00)00033-5.

Mumford, M. D., Gustafson, S. B. (1998). Creativity syndrome: Integration, application, and innovation. Psychological Bulletin, 103, 27-43. DOI: 10.1037/0033-2909.103.1.27.

Nixon, F. (1974). Jakość i niezawodność a zarzadzanie przedsiębiorstwem. Warszawa: PWE.

Nowak, E. (1994). Decyzyjne rachunki kosztów. Warszawa: Wydawnictwo PWN. ISBN

Nowak, E. (2010). Rachunek kosztów przedsiębiorstwa. Wrocław: Ekspert Wydawnictwo i Doradztwo. ISBN 9788389179449.

Nowak, E. (2015). Zarządzanie kosztami zorientowane na strategię przedsiębiorstwa. Studia Ekonomiczne, 229, 133-142.

Nowak, E. (2017). Costs an Economic category exposed to risk. W: E. Nowak, M. Kowalewski (red.). Global Challenges of Management Control and Reporting. Wrocław: Publishing House of Wrocław University of Economics, 195-202. DOI: 10.15611/pn.2017.474.17.

Nowak, E., Wierzbiński, M. (2010). Rachunek kosztów. Modele i zastosowania. Warszawa: Wydawnictwo PWE. ISBN 9788320818505.

Obied-Allah, F. M. (2016). Quality Cost and Its Relationship to Revenue Sharing in Supply Chain. Accounting and Finance Research, 5, 173-189. DOI: 10.5430/afr.v5n3p173.

Paulus, P. B., Dzindolet, M. T., Poletes, G., Camacho, L. M. (1993). Perception of performance in group brainstorming: The illusion of group productivity. Personality and Social Psychology Bulletin, 19, 78-89. DOI: $10.1177 / 0146167293191009$. 
Petrus, B. (2019). Environmental dynamism: The implications for operational and dynamic capabilities effects. Management Sciences, 24(1), 28-36.

Porter, L. J., Rayner, P. (1992). Quality Costing for Total Quality Management. International Journal of Production Economics, 27, 69-81. DOI: 10.1016/0925-5273(92)90127-S.

Shah, K., Mandal, P. (1999). Issues related to implementing quality cost programs - a review. Total Quality Management, 10, 1093-1106. DOI: 10.1080/0954412997082.

Skrzypek, E. (1999). Efektywność działań w TQM. Koszty jakości. Problemy Jakości, 31, 7, 5-13.

Skrzypek, E. (2000). Jakość i efektywność. Lublin: Wydawnictwo UMCS. ISBN 8322716265.

Skrzypek, E. (2003). Koszty jakości jako narzędzie oceny efektywności organizacji. Annales Universitatis Mariae Curie-Skłodowska, Sectio H, Oeconomia 37, 415-439.

Strauß, E., Zecher, C. (2013). Management control systems: A review. Journal of Management Control, 23(4), 233-268. DOI: 10.1007/s00187-012-0158-7.

Teece, D. J. (2007). Explicating dynamic capabilities: The nature and microfoundations of (sustainable) enterprise performance. Strategic Management Journal, 28(13), 1319-1350. DOI: doi.org/10.1002/smj.640.

Zając, S. (2014). Koszty jakości jako determinanty rozwoju przedsiębiorstwa. Prace Naukowo-Dydaktyczne PWSZ im. S. Pigonia w Krośnie, 67, 163-183.

Zymonik, Z. (2000). Koszty jakości w zarządzaniu przedsiębiorstwem. Wrocław: Oficyna Wydawnicza Politechniki Wrocławskiej. ISBN 8370857442.

Zymonik, Z. (2003). Koszty jakości w zarządzaniu przedsiębiorstwem. Wydanie drugie. Wrocław: Oficyna Wydawnicza Politechniki Wrocławskiej. ISBN 8370857442.

\title{
Quality costs in the company's strategy
}

\begin{abstract}
The main goal of the work is to define quality costs (recognition of the perception direction), define their place and role in the strategy of a production company. The research related to producers of parts and subassemblies of agricultural machines intended for the first assembly. Achieving the main goal required the formulation and implementation of partial goals, the authors of which include: (1) enhancing the importance of quality costs from the perspective of management and quality sciences (theoretical layer); (2) nominat-

ing desiderata relevant to the content and scope of research; (3) compiling a research model in the form of an evaluation sheet, which is the result of the exploration of the literature and a study carried out among deliberately selected experts (theoretical and design layer). The concretized explications have become the substrate that defines the right direction of fundamental research (verification of the research model); concretization of quality cost desiderata among producers of the agricultural machinery sector (self-assessment).
\end{abstract}

Keywords: quality costs, company strategy, production for the first assembly, agricultural machinery sector 